\title{
NON-SPECIALISTS PERCEPTION ABOUT ENDOKARST AND EXOKARST SCENARIOS: VISIONS FROM HIGH SCHOOL STUDENTS
}

\author{
LAIČNO DOJEMANJE KRAŠKEGA PODZEMLJA IN POVRŠJA: \\ PRIMER VISOKOŠOLSKIH ŠTUDENTOV
}

\author{
Luiz Eduardo Panisset TRAVASSOS ${ }^{1}$; Edson Gomes TRAVASSOS ${ }^{2}$, Lucília Panisset TRAVASSOS ${ }^{3}$ \\ \& Luiz Carlos Panisset TRAVASSOS ${ }^{4}$
}

\begin{abstract}
UDC 159.937.52:551.44

Luiz Eduardo Panisset Travassos \& Edson Gomes Travassos \& Lucília Panisset Travassos \& Luiz Carlos Panisset Travassos: Non-specialists perception about endokarst and exokarst scenarios: visions from high school students

The aim of this work is to recover some methodological aspects of the study about the mind representations of caves in Brazil. The basis of this research consisted of one essay, approaching the social representations of a particular group of high school students on the exokarst and the endokarst. The results showed that the meanings vary only slightly, however, the most interesting result was due to the fact that students, who had already visited caves in some period of their lives, still held "negative" concepts regarding this environment even before visual stimulations. About 640 words associated with the exokarst and the endokarst were mentioned, emphasizing: fear, dark, shadowy, skull, hidden places, fantastic and beauty, which helped identifying relations between the cultural and psychological aspects of the group, mainly general views about the obscure and mysterious aspects of this landscape and its prominence over natural beauties. Analyzed data showed that the development of new research on mind representations of caves is very important, mainly for environmental education programs promoting adequate concepts about caves and extending activities of educational ecotourism in Brazilian caves.
\end{abstract}

Key words: mind representations, environmental perception, symbols, caves.
Izvleček

UDK 159.937.52:551.44

Luiz Eduardo Panisset Travassos \& Edson Gomes Travassos \& Lucília Panisset Travassos \& Luiz Carlos Panisset Travassos: Laično dojemanje kraškega podzemlja in površja:

primer visokošolskih študentov

Cilj tega dela je potrditi nekatere metodološke vidike preučevanja duhovne predstave o jamah v Braziliji. Osnova te raziskave je poizkus, približanje družbene predstave določene skupine visokošolskih študentov o površinskem in podzemeljskem krasu. Izsledki kažejo le majhne medsebojne razlike. Vsekakor pa je najpomembnejši izsledek, da študentje, ki so že kdaj v svojem življenju obiskali kako jamo, imajo do podzemeljskega okolja "negativen« odnos, še pred vizualno stimulacijo. Naštetih je bilo okoli 640 besed povezanih s kraškim podzemljem in površjem, vključno: strah, tema, sence, lobanja, skrivališče, fantastičen in čudovit, kar pomaga določiti razmerje med kulturnimi in psihološkimi pogledi skupine, namreč splošni pogled na obskurni in skrivnostni vidik te pokrajine ter prevladovanje tega nad naravno lepoto. Obdelani podatki kažejo, da je zelo potrebno razvijanje novih raziskovalnih metod v zvezi z duhovnimi predstavami jam, to je okoljskih vzgojnih programov z ustreznimi koncepti o jamah in da je potrebno razširiti izobraževanje v ekoturizmu tudi na brazilske jame.

Ključne besede: duhovna predstava, zaznavanje okolja, simboli, kraško površje, jama, Brazilija.

${ }^{1}$ PUC Minaes, Environmental Studies Laboratory. Avenida Itaú 505 - Prédio Emaús - Belo Horizonte, MG, Brasil; e-mail: luizpanisset@gmail.com / luizpanisset@uol.com.br

2 A Practica do Conhecimento Educational Consulting, Alameda Centauro 72, Ville de Montagne - Nova Lima - MG - CEP: 34000-000. Faculdade Promove de Belo Horizonte, Brasil; e-mail: egtravassos@uol.com.br

${ }^{3}$ A Practica do Conhecimento Educational Consulting, Alameda Centauro 72 - Ville de Montagne - Nova Lima - MG - CEP: 34000-000, Brasil; e-mail: luptravassos@egc.ufsc.br

${ }^{4}$ A Practica do Conhecimento Educational Consulting, e-mail: luizcpanisset@gmail.com

Received/Prejeto: 30.01 .2007 


\section{INTRODUCTION}

As it is known, human relations with caves take us back to times of cults and myths of highly symbolical meaning, depicted by cave paintings or in the representations of caves as birthplaces of gods, heroes and nymphs.

In some other cases, karst regions and caves appear as places where conflicts between the good and the evil took place, as sacred or profane sites, and sites where topophilic or topophobic feelings could be expressed especially by folk tales and traditions. Therefore, mind representations determine, in its essence, the development of human beings and its social existence.

When studying collective mind representations (the imaginary), we are compelled to understand that "mental imaging systems and its defining structure as to facilitate understanding of the dynamics of images are incorporated as collective content, resulting in visualization, social representation and preconception that could compromise the quality of a view about a particular environmental scenery."(Figueiredo 1999, 165)

For many authors, however, studies about collective mind representations could be considered as an instrument of knowledge and comprehension of a particular social group. "Each culture, each community and, even each level of a complex community has its imaginary, which manifests itself from human experience, from the most social collective through to the most intimately personal " (Mendes 2003, 72) by which society expresses its

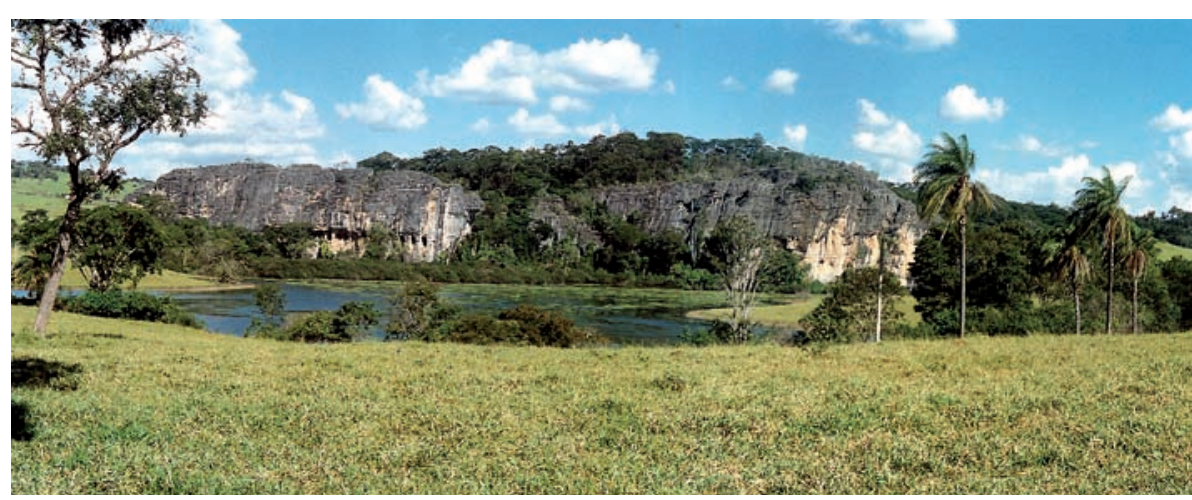

Fig. 1: General view of the Cerca Grande massif, Matozinhos (MG) (ph. H.C. Kohler). 1999, 165). ritual. The Legend states that, after a ritual, the cave closed giving way to the opening of another cave, where Catholic masses take place nowadays.

When mentioning Figueiredo, Meneses warns us that concepts of image, imaginary and imagination have the fact they all refer to the spectrum of sense and meaning in common. They involve the phenomena of production, storage, circulation, consumption, recycling and discharge of operations as well as meanings that are fundamental to the formulation and establishment of hierarchy of values generated by any given community, essential to its organization (Meneses apud Figueiredo

And this is how the concept and pre-conceived images about caves appear. History shows that the human being has always been connected to karst areas, either for ritual activities or contemplative ones. As it is already known, pre- Colombian civilizations used caves as drinking water fountains, for religious rituals, burial ground and refuge, for instance.

The magnificence of the exokarst and the beauty of the endokarst are the sources for the development of collective mind representations (imaginary), "important element for the rising of legends and fables associated with more common myths" (Teixeira et al. 2003, 11), where the myth function is the fixing point to exemplary models of several rituals and expressive human activity such as feeding, sexuality, work, education, moral, etc. (Elaide apud Teixiera 2003).

It is believed that the most common studies about the human relation with caves are those related to myths and not to legends, since myths have figures that are common to cultures and varied places. This is the case with the apparition of Our Lady of Lourdes (France), the images of Our Lady of Lapa, in Portugal (15th century), in

temperament, its character, its doubts and desires when trying to establish a broader sense of perspective to human existence. Such a fact can make people share the same way of thinking (Mendes 2003).

We can use a regional Brazilian Legend (Lenda do Lapão Velho) as an example to illustrate a social group temperament expression, written by Mendes (2003), showing discrimination and religious intolerance with the practice of candomble, an African type of religion/
Antonio Pereira, Minas Gerais (Brazil, 18th century), or in Vazante, Minas Gerais (also in the 18th century). In these places percolation of water in the cave (Lapa) walls is related to the apparition of the Saint, giving miracle properties to the water.

As to caves, some people do fear them for believing that they are homes of strange beings and its rooms can sometimes take them to places with no way out. Such places can also be a ground to be respected for its natural 
beauty, the healing power of its waterways and its divine origin (Mendes, 2003).

Silva (2003) says that, for a "rational" contemporary society, a myth is always born from a fantasy explanation of reality, inferior to scientific knowledge, and sometimes the history behind myths hide records of some political and religious aspects of a region.

To understand the relation between the individual and the space under consideration, ideas and exposed concepts is the same as understanding the human experience with the environment in all its complexity. Yet, people can understand feelings, perceptions, attitudes and underlying behaviors under a holistic conception of relations between individual or collective spaces, either known or unknown, which in counterpart can become places or not (Silva 2002).

Plato, the Greek philosopher, used a cave imaging as a metaphor to reveal the duality between the sensible and the tangible world, influencing thought through the "Cave Allegory". Everything that "the prisoner", the main character, knew as reality was only a reflex, artificially created inside the cave, without much similarity to what existed in the real world.

Comelim (1993) says that in the Classic Ancient Greek and Roman mythology hell was considered as an underground place to where souls would be sent after death. Such places were located deep under Greece and Italy, extending through to the extremes of the world. Therefore caves, cracks or openings on the ground would be gates to hell that no one would dare to explore.

According to Aranha and Martins (1992), the illuminists disregarded imaging/imagination when saying that the imaginary and the concrete reality are contradictory, sources of illusion, fantasies, the lack or denial of reason. Therefore, such collective representations did not contribute to the development of science.

For Mariano Neto (2003), by the 18th and $19^{\text {th }}$ centuries there were only fragments left from Plato, as a foundation for critics about the domain of reason as the only source to access truth. Such fragments displayed some forms of resistance to the dogmatic rationalism shown by Kant in his work "Critique of Pure Reason"(1781).

"Criticism in the nineteenth century was aimed at the excess of Cartesian Mechanicism. Maybe that is where we can find the first steps towards rescuing image not only as the object of knowledge but as a whole object capable of representations." (Sartre 1980, 327).

With the arrival of the 20th century, man is not only living the moment of the practice and exercise of modern science principles but also a moment of intense polemics in relation to the real, the reason and the imaginary (Mariano Neto, 2003).
Nevertheless, shifting away from these paradigms is extremely difficult according to Mendes $(2003,72)$, who believes that "domain of imaginary is a group of representations that lays beyond the limits of confirmation. Each culture, therefore, each society and even each level of society has its own imaginary, which appears as a result of all its human experience, from the most social collective through to the most intimate personal one".

A recent movie, "The Cave" (2005), depicts a group of scientists facing the dilemma of discovering the ruins of a 13th century Church in Romania, that was obstructing the entrance to a huge underground cave, home to demon creatures, confirming the negative feeling a lot of people nurture about this type of environment. It is worth mentioning that, as it has been already said, the Church exists as a symbol of protection against the so called "gateway to hell" of ancient times. Another movie, "The Descent" (2005), has its plot based on a frustrated speleological expedition and the characters found themselves corned and threatened by horrendous creatures.

"The Chronicles of Narnia" establishes an analogy to caves when it is mentioned that the shadows of a wardrobe could take people to a magical world. A world dominated by a witch that lives in an ice cave/castle. At the end, the fight between the good and the evil takes place at a beautiful poljé, a place of majestic beauty emphasizing the general idea of fascination for the exokarst.

In the book "Landscapes of Fear", Tuan (2005) mentions the work done by Berr (1930) about a great Alpean explorer, Johann Jacob Scheuchzer. This particular explorer dedicated all his life to the study of plants, minerals and ice movements of the European Alps, from 1702 to 1711 , creating a catalogue of Swiss dragons.

According to the author, "the best dragons lived in Grisons, the biggest and the least densely inhabited place of remote Swiss. This region is so rugged with so many caves that it would be strange not to find dragons there." (Berr apud Tuan 2005, 129).

Interest in this kind of subject is due to the disseminated views related to the exokarst, which are normally linked to positive feelings, to religion and to the glorification of natural beauty and leisure, whereas those linked to the endokarst sometimes display negative feelings, such as dark and muggy places, as well as housing for unthinkable creatures.

People fear caves because they believe in supernatural occurrences, places where "animals are hidden or places where beings from other worlds live (...), in other places however we are going to find caves that are respected, with a mystical aura around it or a scenery of religious manifestations" (Mendes, 2003, 77-78).

According to Marin, Oliveira and Comar (2005), we cannot understand the relationship between man and 
the environment without taking in consideration those non-rational human dimensions. In this specific case, the imaginary clearly defines the social existence and the relation with space/place, so that when we talk about environmental perception we consider the several possibilities of associated symbol construction.

To some, in the words of Barbosa, Nogueira and Neves (1999 71), "the so called cave mouth is a lot more than a simple entrance, its is a portal, a passage to a new universe where rats change into bats, a place where God imprisoned Satan (...)" or even the confirmation of a divine creation that must be adored and preserved, where water turns into rock.

On considering Humanistic Geography, we can notice the recent display of the environmental perception tendency in a lot of sciences, underlying phenomenology and existentialism, valuing man personal experiences with its environment for the implementation of more efficient strategies in the practice of environmental education. According to Ribeiro (2004), because this is a pedagogical process, it requires time and monitoring, aim adjustments and constant attention.

Therefore, it is believed that investing in environment perception is of fundamental importance in order to improve our knowledge and be able to best explain certain attitudes and values of a given social group in relation to its environment. "Human studies are aimed at the relations established by individuals, feelings, percep- tions and attitudes of human being about space and place as far as live experience" (Silva 2002, 73)

Humanist researchers are turning themselves to the comprehension of experiences, perceptions and habits of social groups or individuals with places and non-places, seeking to find it in phenomenology, "the most important philosophical basis of Humanistic Geography that consider all knowledge as derived from the world of human experience, where ideas and other things are indissolubly linked into each other, making up only one phenomenon." (Silva 2002, 78)

In his work about topophilia, Tuan $(1980,26)$ says, "a symbol is a part with the power to suggest a whole (...). In such a rich world in terms of symbols, objects and events take on meaning which can seem to be arbitrary to estrangers". Some forms of interaction with spaces turn them into places, in a process of adding values that sometimes are not understood by those people alien to certain social groups.

Patlagean (1990) considers the collective imaginary as a group of mental representations that extrapolate boundaries of confirmation by experiences and by authorized deductive connections. From that point on this research seek analysis of man capacity of giving meaning to symbols, showing its importance for comprehension of collective values; further enhancing work related to human representations of caves.

\section{MATERIAL AND METHODS}

Because it's believed that studies of karst can dwell perfectly in the field of physical and human research, the work was carried out from bibliographic analysis of the relations between mind representations, the imaginary and caves. Furthermore, this discussion was enhanced by knoweledge exchange with a close friend, Professor Luiz Afonso Vaz de Figueiredo and other colleagues interested in the subject.

The methodology was adopted and adapted from Figueiredo (1999) and the main methodological focus was the creation of an exploratory essay, in February 2006, with the aim of establishing a diagnosis about the view of a certain group of students about karst landscapes. The authors felt the need to treat the subject with the group after a brief explanation about the karst ecosystem, which sometimes attracted negative questioning.

Thus, the study about social representations of the cave concept was developed and divided in two parts, involving 67 high school students from two different 11th

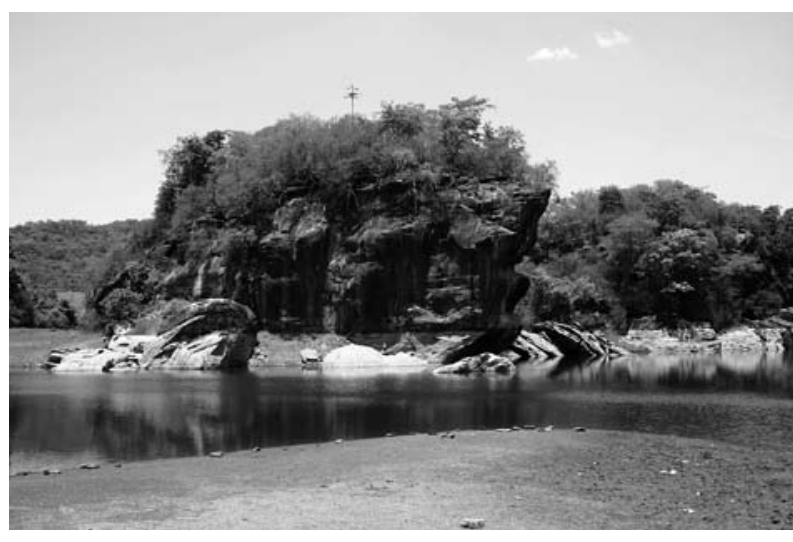

Fig. 2: Hum of Vargem da Pedra, Matozinhos (MG) (ph. L. Travassos).

grade classes of a private school in the city of Belo Horizonte, State of Minas Gerais, Brazil.

In those two groups, collective interviews were conducted, starting from a direct stimulus related to their 
pre-concept of caves. They were asked to record 5 (five) key words about the word cave, writing the first ideas that would come to their minds when the word cavernas (caves) was mentioned. After recording those key words, they would answer whether they had already visited any cave before and if they had any intention of doing so in the future.
In the next activity the interview was started from another direct stimulus related to the theme, when after viewing 5 (five) slides, each student should record one single key word for each image and answer the same question about visiting a cave. Slides included images of the exokarst and the endokarst, such as cave entrances, dolines and speleothems.

\section{RESULTS AND DISCUSSION}

Regarding the characterization of the public interviewed the following data was gathered: it occurred the predominance of female interviewees (53.7\%), against $46.3 \%$ males. Out of these, $67 \%$ had already visited a cave against $33 \%$ students that have never visited a cave before.

Results showed that the values given to caves did not vary much between the two groups, for they were relatively equal in terms of age, between 17 and 18 years old, and at the same social level. However, some variations were noticed when the stimulus was treated through slides that demanded even more personal perceptions.

Inside the two groups, two sets of 335 words were registered associated with the noun cave (with some recurrence) and the other 335 related to the keywords after a visual stimulus.

Records were restricted in its majority to the words that expressed negative feelings such as fear, darkness, shadowy, muggy, skull, hidden places, dragons, loneliness, lack of breath, mystery, danger, animals, amongst others, even in the universe of students that had already visited a cave before.

Besides, a curious phrase was recorded: "a place to whisper". When confronted about the motive of someone having to whisper in such an environment, the answer also had a negative meaning, being justified because "if we are to talk loudly a stalactite could fall and kill people."

After being asked about the reason for someone to express topophobic feelings in relation to caves, even after having already experienced that environment, some of the students said they had not visited a cave in the company of someone that knew what he was doing or saying. Such a scenario shows the importance and need of truly qualified guides in any tourist activity, mainly in the tourism related to caves.

Even with all the symbolism related to "caves", we can still identify words from scientific background such as stalactite, prehistory, rock, water, natural beauty, biodiversity, intemperism, acidulation, amongst others, depicting previous contact with the theme.

After the visual stimulus about the exokarst and the endokarst, words such as fantastic, wonderful, awesome, knowledge, tranquility, force, adventure and perfection could be identified, and around $98 \%$ of the interviewed students who had never visited a cave before showed desire to do so in the near future.

According to Figueiredo (1999), the question of collective imaginary about caves is present in the verbal tradition of the population that lives in its vicinity. Such representations are also shared by those living in urban areas who have already had a chance to visit a cave or have the desire to do so.

People from the cities normally receive a massive quantity of information about speleological activities through the media or store misguided representations throughout their lives leading mainly to wrong views about this type of environment. Fear of bats or other animals are common occurrences. Lack of air is automatically evoked when we talk about the underground.

A closer look at the data confirmed the need of a series of studies emphasizing the importance of developing effective programs of Environmental Education in order to facilitate learner access to better quality of information about the karst environment. In 1781, Immanuel Kant said that only reason can be limited by the senses contribution and this is why we cannot produce a complete set of knowledge about reality. Therefore, the reality perceived by students is extremely influenced by the senses, mainly at the age of the group surveyed.

For Tuan (1980) the meaning of perception, attitude and values overlay themselves, clarifying the context expressed in each of these processes. Such processes consider that adopted attitude to the world is formed by a long path of successive perceptions and experiences. Attitudes adopted by people in relation to their environment reflect their interests and values and their personal view of the world. It is therefore a conceptualized experience, partly personal, and in its majority, social.

With this study we verified the need of further elaboration in such a theme for this particular group of people, and the importance of a more technical and structured visit showing the reason behind environment preservation, mainly of the Karst. Guide training and teacher 
awareness can contribute enormously for a change of feelings in relation to the underground world.

Therefore, studies about perception and the imaginary must be seen as a phase in human relation with the environment, and it is important to involve community in the solution of possible problems.

We are aware that field work represents an extension of "conventional" school syllabus for subjects of the so called Earth Sciences, indispensable for the consolidation of theories and concepts that somewhat contribute to the development of specific abilities in some areas of knowledge.

Practical exercises of geographical landscaping watch, development of sensory abilities for environment perception and comprehension of basic notions of positions for orientation are essential in the formation of conscious citizens capable of exercising full citizenship.

The line of reasoning used in this work agrees with Serpa (2001) when he says that the environment perception, personal experience and cultural characteristics of the inhabitants in each place play an important role in the relation between man and the environment, and must be used as a starting point for a better urban, regional, landscaping and environmental planning. Then the chances of local people's needs being met become higher and better.

"Environment perception is, in this sense, a vehicle that identifies memory rescue, being able to reveal and even justify behavioral patterns in relation to human

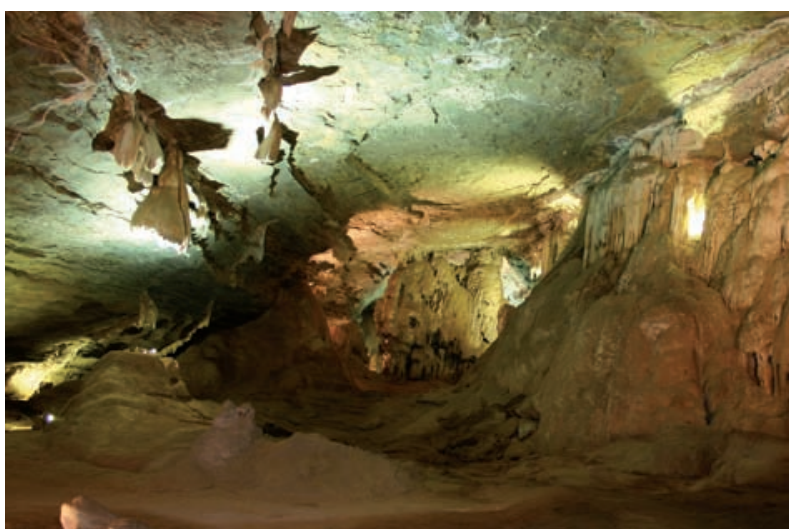

Fig. 3: The first cave arranged for tourist visit in Brazil, Napa Nova do Maquiné, Cordisburgo (MG) (ph. L. Travassos).

being and its environment". (Marin, Oliveira \& Comar $2004,104)$. As it has been said before, if caves are feared or adored by certain groups, we must seek to decode which are messages being transmitted.

It is known that karst landscapes have a dynamic physical-chemical peculiarity and because of this, they are more sensitive to the exploitation of its resources. Many qualitative and quantitative studies deal with the processes related to the physical, biotic and economical environment but we can't disregard any work that approach this landscape under a more holistic view, not forgetting cultural and human variables.

\section{REFERENCES}

Aranha, M. L. A. \& Martins, M. H. P., 1993: Temas de filosofia. São Paulo, Moderna.

Barbosa, E.P. \& Nogueira, K.A.B. \& Neves, N.G.S. das., 1999: Caverna, história e tradição popular no sertão baiano. In: Congresso Brasileiro de Espeleologia, 25,1999,Vinhedo. Proceedings... Vinhedo-SP: Trupe Vertical/SBE/Prefeitura Municipal de Vinhedo, 1999, 69-74.

Comelim, P., 1993: Mitologia grega e romana. São Paulo, Martins Fontes.

Chaui, M., 1999: Convite à filosofia. São Paulo, Ática.

Figueiredo, L.A.V. de., 1999: O imaginário, o simbólico e as cavernas: estudos preliminares.. In: Congresso Brasileiro de Espeleologia,25,1999,Vinhedo. Proceedings... Vinhedo-SP, Trupe Vertical/SBE/Prefeitura Municipal de Vinhedo, 1999, 165-171.

Gomes, P.F., 2003: A sociedade e a produção do imaginário no município de Santa Luzia. In: Teixeira,
G.M. (Org.). O Imaginário das grutas. Ilhéus/Bahia, UESC/CEDOC, 2003, 47-70.

Mariano Neto, B., 2003: Topofilia, ecologia e imaginário: os velhos cariris da Paraíba. Para'iwa - Revista de Pos-Graduandos de Sociologia da UEPB, 4, set 2003.

Marin, A.A. de; Oliveira, H.T.; Comar, V., 2005: Percepção, imaginário e educação ambiental. OLAM - Ciência \& Tecnologia, Rio Claro/SP, 5(1), 188-201, maio 2005.

Marin, A.A. de; Oliveira, H.T.; Comar, V., 2004: Reconstituição histórica como instrumento de resgate cultural e de educação ambiental. Rev. Eletrônica Mestr. Educ. Ambient. Rio Grande, FURG, 13, jul/ dez 2004.

Marinho, P. A., 2005: Representações sociais da Mata Atlântica, sua caracterização e impactos ambientais: estudo de caso da concepção de estudantes universitários da região do Grande ABC, SP. Relatório Fi- 
nal (Bolsa de Iniciação Científica) - Colegiado de Ciências Biológicas, Faculdade de Filosofia, Ciências e Letras, Centro Universitário Fundação Santo André, Santo André, SP, 2005.

Mendes, S. R., 2003: O imaginário como objeto da História. In: Teixeira, M.G. O imaginário das grutas. Ilhéus, Editora da UESC, 71-107.

Ribeiro, L. M., 2004: Sobre a percepção: contribuições da história para a educação ambiental. OLAM - Ciência \& Tecnologia. Rio Claro/SP, 4(1), 649-665.

Sartre, J. P., 1980: A imaginação. Rio de Janeiro, DIFEL.

Sartre, J. P., 1996: O imaginário - psicologia, fenomenologia da imaginação. São Paulo, Ática.

Serpa, A., 2001: Percepção e fenomenologia: em busca de um método humanístico para estudos e intervenções do/no lugar. OLAM - Ciência \& Tecnologia. Rio Claro/SP, 1(2), nov 2001, 29-61.

Silva, C.A.da, 2002: O turismo no contexto da Geografia Humanística: espaço e lugar. Boletim Goiano de Geografia, 22(2), 73-92.
Silva, D.C., 2003: Jacarandá - Vida e morte de um povoado. In: Teixeira, G.M. (Org.).O Imaginário das grutas. Ilhéus/Bahia: UESC/CEDOC, 29-46.

Teixeira, G.M.(Org.) \& Silva, D.C. \& Gomes, P.F. \& Mendes, S., 2003: O imaginário das grutas. Ilhéus/ Bahia, UESC/CEDOC.

Tuan, Yu-fu., 1980: Topofilia: um estudo da percepção, atitudes e valores do meio ambiente. São Paulo/ Rio de Janeiro, DIFEL.

Tuan, Yu-fu, 1983: Espaço e lugar. São Paulo, DIFEL.

Tuan, Yu-fu, 2005: Paisagens do medo. Tradução de Lívia de Oliveira. São Paulo, Editora UNESP.

Vieira, S.E.M., 2005: Imaginário e percepção dos moradores locais sobre as serpentes da região de Paranapiacaba (Santo André-SP). 2005. Relatório Final (Bolsa de Iniciação Científica) - Colegiado de Ciências Biológicas, Faculdade de Filosofia, Ciências e Letras, Centro Universitário Fundação Santo André. Santo André, SP. 